\title{
The Impact of Entrepreneurship Education and Project-based Education on Students' Personal Development and Entrepreneurial Intentions at the Lower Levels of the Educational System Too Much of Two Good Things?
}

\author{
Moberg, Kåre
}

Document Version

Final published version

Publication date:

2012

\section{License \\ CC BY-NC-ND}

Citation for published version (APA):

Moberg, K. (2012). The Impact of Entrepreneurship Education and Project-based Education on Students'

Personal Development and Entrepreneurial Intentions at the Lower Levels of the Educational System: Too Much of Two Good Things? Institut for Strategic Management and Globalization. SMG Working Paper No. 4/2012

Link to publication in CBS Research Portal

\section{General rights}

Copyright and moral rights for the publications made accessible in the public portal are retained by the authors and/or other copyright owners and it is a condition of accessing publications that users recognise and abide by the legal requirements associated with these rights.

Take down policy

If you believe that this document breaches copyright please contact us (research.lib@cbs.dk) providing details, and we will remove access to the work immediately and investigate your claim. 
The Impact of Entrepreneurship Education and Project-based Education on Students' Personal Development and Entrepreneurial Intentions at the Lower Levels of the Educational System: Too Much of Two Good Things?

\section{Kåre Moberg}

SMG WP 4/2012 
SMG Working Paper No. 4/2012

July, 2012

ISBN: 978-87-91815-81-2

Department of Strategic Management and Globalization Copenhagen Business School

Kilen, Kilevej 14A

2000 Frederiksberg

Denmark

www.cbs.dk/smg 


\title{
THE IMPACT OF ENTREPRENEURSHIP EDUCATION AND PROJECT-BASED EDUCATION ON STUDENTS' PERSONAL DEVELOPMENT AND ENTREPRENEURIAL INTENTIONS AT THE LOWER LEVELS OF THE EDUCATIONAL SYSTEM: TOO MUCH OF TWO GOOD THINGS?*
}

\author{
Kåre Moberg, PhD-student \\ Department of Strategic Management and Globalization \\ Copenhagen Business School \\ Kilevej 14, 2000 Frederiksberg, Denmark \\ and \\ The Danish Foundation for Entrepreneurship - Young Enterprise \\ Ejlskovsgade 3D, 5000 Odense C \\ kmo.smg@cbs.dk
}

Prepared for European Summer University Conference 2012

JEL codes: A21, I21, I25, I28, J24

\begin{abstract}
I present an analysis of a survey in which the effect of entrepreneurship education and projectbased education on students at lower secondary level is investigated. The results are based on a random sample of 2000 Danish students. The analysis indicates that entrepreneurship education has a positive effect on students' personal development, and that its effect on entrepreneurial intentions is fully mediated by its effect on students' self-conception. A finding with important policy implications is that there is a negative interaction effect between entrepreneurship education and project-based education regarding impact on students' self-conception. The implication of the results is that we should replace project-based education with entrepreneurship education rather than having them run in parallel.
\end{abstract}

\footnotetext{
*The author would like to thank Jacob Lyngsie and Nicolai J. Foss for their insightful comments on an early version of the paper.
} 


\section{Introduction}

During the last decades the assignments of the educational system have changed. It is no longer sufficient to be an institution that transfers knowledge and information to students; the focus today should be on becoming a learning environment that teaches the students how to apply their knowledge (Biggs and Tang 2007). Entrepreneurship education, with its focus on transforming ideas into action, has played a prominent role in this transformation (Gibb 2002). The topic, though, is still seen as a new and unproven addition to more established pedagogical methods such as project-based and problem-based learning (Löbler 2006). However, the increased interest in the topic has spurred a demand for evaluations of its impact, not only regarding its effects on the students' entrepreneurial behaviour but also regarding their educational performance (Nakkula, Pineda, Dray and, Lutyens 2003; Nakkula, Lutyens, Pineda, Dray, Gaytan, and Hugulay 2004).

Within the field of educational science, there has been a strong focus on the role that the educational system plays in connecting our youth to their future roles in society (Firestone and Rosenblum 1988). Much focus has, thus, been given to the role education plays in the students' personal development processes (Illeris 2009) and their attachment towards their school and educational process (Battistich, Solomon, Kim, Watson, and Schaps 1995). Practice-based education, which is almost always implemented as project-based education in Western countries (Knudsen 1999), has proven to be an effective approach in strengthening this development (McKay and Kember 1997). Within the field of entrepreneurship education, however, the focus has rather been on entrepreneurial outcomes and whether or not we can "create entrepreneurs" (Nakkula et al. 2003). Entrepreneurship education is a practice-based approach (Katz 1995) and should, as such, have similar effects on education-related dimensions as project-based education. Unfortunately, we know very little about whether it is the content or the teaching methods of entrepreneurship education that generates the outcomes which previous evaluations of entrepreneurship education have established (see for example: Fayolle, Gailly, and Lassas-Clerc 2006; Peterman and Kennedy 2003; Souitaris, Zerbinati, and Al-Laham, 2007). 
This paper addresses the effect that entrepreneurship education and project-based education have on students' entrepreneurial intentions but also their effect on students' personal development, defined here as their level of self-conception and future orientation. The analysis shows that both entrepreneurship education and project-based education, by themselves, have a positive effect on students' personal development. It is, however, only entrepreneurship education that has a significantly positive effect on students' self-conception when the educational approaches are compared to each other. The effect of entrepreneurship education on entrepreneurial intentions is fully mediated by this variable, whereas project-based education has no effect on this outcome. A puzzling finding is that there is a negative interaction effect between entrepreneurship education and project-based education regarding their effect on students' self-conception. A theoretical discussion as to why this is the case, based on the different conceptualisations of experience within the two educational approaches, is presented.

The findings build on a survey targeting 2000 randomly selected 15-year-old Danish students at lower secondary level. The survey design solves the problem of self-selection, a very common problem in programme evaluations of entrepreneurship education, as the students at this level do not get to choose their educational approaches. The Hemingway Measure of Adolescent Connectedness (Karcher 2003) has been used in order to measure students' level of personal development and school attachment.

\section{Theoretical Background}

During the sensitive junior-high years the young students embark on the process of becoming mature. As a learning institution, the school's responsibility thus goes beyond merely providing students' with knowledge and skills. According to Illeries (2009), the school "serves the personal integration in communities and societies and thereby also builds up the sociality of the learner" (Illeris 2009, p. 11, emphasis in the original). When it comes to adolescent socialization, three aspects are emphasized as having major importance: connection to significant others, regulation of behaviour, and psychological autonomy (Barber and Olsen 1997). Since the pioneering research by Travis Hirschi (1969) on delinquent 
youths, there has been a long line of research that focuses on the two first of these (Demanent and van Houtte 2012). The importance of school attachment, which refers to the student's feelings about school, teachers and peers, has been emphasized in many studies (see for example: Jimerson, Campos, and Greif 2003; Libbey 2004). This line of research is closely related to the theory of adolescent connectedness (Karcher 2001; Karcher and Lindwall 2003), which extends the concept to also incorporate the process of constructing an enduring self (Karcher 2003). This extension puts the focus on personal development, such as the student's relation to herself and her future, rather than just her school attachment (ibid). This is closely in line with the goals of our education system, and it has been shown to have positive effects on youth development (Baumeister and Leary 1995; Lee and Robbins 1995).

Practice-based education has proven to be an effective approach in enhancing student development (see for example: Albanese and Mitchell 1993; Mason 2004; Minnaert and Janssen 1999). This approach emphasizes that purposeful learning can only be accomplished when individuals reflect on their experience from practice (Loyens, Magda, and Rikers 2008). The process of learning through practice mimics real life learning and helps the student to meaningfully grasp the learning process as the link between abstract knowledge and concrete applications becomes tangible (ibid). According to the educational researchers Biggs and Tang (2007), this bridging of the divide between the world of abstract ideas and real world application is fundamental if we want to create intrinsically motivated students, meaning students who want to learn out of their own interest.

Practice-based learning is typical for entrepreneurs who go through different venture stages which all have different tasks and associated learning needs (Gibb 1987). Even though there are many opinions within the field of entrepreneurship education regarding what the field should include as well as which specific elements that separate it from other fields, it is commonly agreed that entrepreneurship is about action and implementation and, as such, it is a phenomenon with a very practical focus (Katz 1995, 2003, 2008). The major disagreement within the field of entrepreneurship research is centred round the role of planning and prediction, and whether or not entrepreneurs use strategic management models or operate 
more intuitively (Alvarez and Barney 2007, 2010). However, both perspectives agree that the topic is best taught practically and should include as many opportunities as possible for students to apply their knowledge hands on (Sarasvathy and Venkataraman 2011). Typical teaching methods that have gained popularity within the field are based on classic practice-based pedagogies (see for example: Johannisson 1991; Kyrö and Niemi 2007; Politis 2005; Sarasvathy 2004).

Entrepreneurship education is however radically different from other practice-based approaches as it specifically focus on the creative process of realizing one's own ideas (Baron 2012). This does not equal business start-up, especially not on lower levels of the educational system, as it could be viewed to be just as entrepreneurial to realize new project ideas or new ideas for events (Foss and Klein 2012; Löbler 2006). The focus of entrepreneurial learning is often translated into understanding the processes of creating new mean-ends under conditions of uncertainty (Sarasvathy and Venkataraman 2011). We can, thus, expect that entrepreneurship education should have a different effect on student development compared to other practice-based topics. However, the relationship between these outcomes and entrepreneurial behaviours remains to be investigated.

\section{The Effect of Practice-Based Education on Student's Personal Development}

In order to investigate the effects of entrepreneurship education it is necessary to compare it to another practice-based educational approach. At the lower levels of the educational system, practice-based education is almost always implemented as project-based education (Knudsen 1999). This makes it a natural candidate for comparison with entrepreneurship education. The focus in my theoretical modelling will be on how these approaches, individually and combined, effect students' personal development, and furthermore how this influences entrepreneurial intentions. Personal development is defined as the students' development of their self-conception and future orientation. This is captured with two constructs in the Hemingway Measure of Adolescent Connectedness (Karcher 2003): connectedness to self in the 
present and in the future. The hypotheses are developed in the following; Figure 1 summarizes the theoretical model.

\section{[Insert Figure 1 here]}

Different Approaches to Experience. Constructing an enduring self is an inter-subjective process and therefore dependent on responses from significant individuals in the student's environment (Ferral 1999). As education is directly attached to the identity process on this level, it needs to be relevant and meaningful and answer the two questions that young students pose: what does this mean to me? and what can I use this for? (Illeris 2009). Practice-based pedagogies, such as project-based education and entrepreneurship education, aim to bridge the gap between the worlds of abstract ideas and practical application. This sets off a learning course where the students understand how new knowledge is related to their present and their future identity (ibid). There are many similarities between entrepreneurship education and project-based education, such as the open-endedness of solutions to problems and the role of the educator as a facilitator, rather than an instructor. However, it can be argued that the concept of experience is different in these two educational approaches.

Project-based learning is a structured methodology with clear stages: a beginning, where the problem is identified and conceptualised, and an end, where the final product is displayed and the problem reconceptualised (Barron, Schwartz, Vye, Moore, Petrosino, Zech and Bransford 1998). In the middle of this process the learning takes place as the students reflect on the experience they gain by executing their project. Entrepreneurship education, on the other hand, is based on the thought that students should test their own ideas in practice (Baron 2012). It is of importance to understand whether or not the opportunity is suitable to oneself, not just if it is a good opportunity per se (McMullen and Shepherd 2006). The acceptance of failure as a valuable learning experience is central within this approach (Sarasvathy 2008), which naturally links the learning process to the emotional experiences of the students (Shepherd 2004). 
In this sense, entrepreneurship education bears strong resemblance with the original concept of experience within philosophical pragmatism expressed by Dewey (1896 [1972], 1916 [1980]), where the focus is on inquiry and "what if" rather than "if then". According to Elkjaer (2009), this conceptualisation of experience has been misunderstood within educational science. Experience has come to mean past actions rather than imaginative and future oriented iterations of ideas and concepts as "tools to think with" (ibid). The most famous example of this misunderstanding is probably Kolb's (1984) learning cycle in which the learners are expected to reflect on past experience and the distinction between action and thinking is divided into different abilities, learning styles and stages (Elkjaer 2009). This conceptualisation of experience strongly resembles the stages in the project-based approach.

The focus in entrepreneurship education on Dewey's original conceptualisation of experience, with iterations and uncertainty at the centre, should create a good environment for conscious experience to arise, as this is typically created when our existing knowledge and world-views are challenged (Jarvis 2009). This challenge of existing world-views is strongly connected to personal development, as it is in the process of agreeing and disagreeing with new knowledge that aspects of our individuality emerge (ibid). The first hypothesis is thus:

H1: Entrepreneurship education has a stronger effect on students' personal development than projectbased education.

Personal Development and its Mediating Effect on Future Roles in Society. As learning is a way to challenge existing world-views, the process of personal development is tightly connected to the educational process (Jarvis 2009). This is often a frustrating process for the student but if it has the intended effects, it will enhance her understanding of who she is, what she is good at, and what she would like to do in her life, both in the present and in the future (Illeris 2009). This process is tightly connected with curiosity (Biggs and Tang 2007). As the student learns more about what makes her unique and what her strengths are, she will begin to reflect more on her possible roles in society and even how she can 
contribute to changing it (Illeris 2009). We would, therefore, expect that this openness to the world and improved knowledge about personal strengths and weaknesses make a career as an entrepreneur a more likely alternative to the student. It can thus be expected that the two personal development variables selfconception and future orientation have a positive effect on entrepreneurial intentions.

As the effects of practice-based approaches are intimately connected to their impact on how students understand new knowledge and how this is related to their present and their future identities, it is natural that these approaches' effect on students' thinking about future roles in society are mediated by personal development. In the case of entrepreneurship education this goes even further, as the learning course ideally should start with the student identifying who she is, what she knows and whom she knows (Sarasvathy 2008), before future opportunities are conceptualised, but this can also be an outcome of the process itself (Baron 2012). The second hypothesis is thus:

\section{H2: The effects of entrepreneurship education and project-based education on entrepreneurial intentions} are mediated by personal development.

\section{Method}

In order to investigate the relationship between entrepreneurship education and project-based education and their effect on personal development, stepwise regression was used. This method was also used in order to investigate the educational approaches' effect on entrepreneurial intentions and the mediating effect that personal development has on this outcome. In both of these regression models a baseline model has been constructed consisting of control variables that previous research has shown to be important. These control variables were of demographical nature: gender, educational and entrepreneurial background of the parents, and ethnicity (see for example Matthews and Moser 1996, for their impact on entrepreneurial outcomes, and Majoribanks 1996, for their impact on academic achievements). Included in the baseline model were also the students' work experience, general attitudes towards entrepreneurship 
and two school attachment variables connectedness to school and connectedness to peers. In the following, the sample and the specific measures used in the analysis will be described.

\section{The Sample}

The data were part of the SIEED (Survey of the Impact of Entrepreneurship Education in Denmark) gathered in September 2011 by the Danish Foundation for Entrepreneurship - Young Enterprise (www.ffe-ye.dk). In collaboration with the Danish population registration authority, the organization accessed personal identification numbers of 2000 randomly selected 15 -year-old students who attended their ninth year of education in the Danish educational system. Information about name, gender and home address was accessed. The survey was sent out by mail to the home addresses of the students. The mail included a cover letter which described the purpose of the survey and the organization behind the survey, as well as a stamped envelope for the return of the questionnaire. They were informed that they would get a cinema ticket if they replied to the survey. 921 responses were collected in total. Only questionnaires with complete responses to all questions were used. This resulted in a sample with 724 respondents. In table 1 the descriptive statistics are presented.

[Insert Table 1 here]

The students were asked three questions related to the background of their parents. As the survey was sent to the students' homes, they could easily access this information. The students were asked to indicate the level of education of the parent with the highest education. They were given five alternatives (Basic school; Upper secondary/Vocational; Academy profession "2-3 years”; Professional bachelor "3-4 years"; University "3-5 years"). The most common educational level was 3-4 years professional bachelor (38 percent). The students were also asked to indicate if their parents were self-employed. They were given 
four alternatives: No; Yes - mother; Yes - father; and Yes - both. 25 percent had either a mother or a father who was self-employed. The third question related to the parents' background was about ethnicity. The students were asked if they, their parents or their grandparents had their roots in another culture. 23 percent indicated that this was the case. The students were also asked to indicate if they had any paid work outside school. They were given five alternatives: Yes -2 days or more a week; Yes -1 day a week; Yes - less than 1 day a week; Yes - work only during holidays/vacations; and No - have no paid work next to school. 59 percent indicated that they had some kind of paid work.

\section{Measures}

In all the cases where categorical variables were not used, the students were asked to indicate on a four-point scale to what extent they agreed to the statements posed in the question. The scale ranged from I do not agree at all (1) to I agree completely (4). Because the respondents were of a young age, this limited response range is essential (Deci, Hodges, Pierson, and Tomassone 1992). Within the psychometric tradition it is preferred that multiple items are used for measurements of abilities and traits (see for example Nunnally 1978), but when a construct can be conceptualized as concrete, it is better to use single items (Rossiter 2002). All latent constructs in the model, such as the connectedness constructs and general attitudes towards entrepreneurship, were captured with multiple items, but the two educational treatments were captured with single items.

Educational Approaches. The extent to which the students had been the subject of the two educational approaches was measured with the questions: "In school I have been taught how to create a new activity or starting a company" (Entrepreneurship education, mean $=1.72, \mathrm{SD}=0.84$ ), and "In school I have worked project-oriented and across subjects" (Project-based education, mean = 3.20, SD =0.84). The high mean value of project-based education, compared to that of entrepreneurship education, indicates that this type of educational approach is much more established within the Danish educational system. 
Personal Development. Two constructs from the Hemingway Measure of Adolescent Connectedness (Karcher 2003) were used as a proxy for the students' personal development, that is, their self-conception and future orientation. These constructs were connectedness to self in the present and connectedness to self in the future.

Connectedness to self in the present, which in the analysis is used to measure the level of students' self-conception, is a six-item construct that measures how well the students perceive how they are connected to themselves, their abilities and interests. Students were asked to indicate if they agreed to statements such as "I have unique interests or skills that make me interesting". Scores were summed to a scale ranging from 6 to 24 (mean $=19.07, \mathrm{SD}=3.01$, alpha $=0.67$ ).

Connectedness to self in the future is, like the previous scale, measured with six items. In the analysis it is used to indicate the level of students' future orientation. This construct captures how well they are connected to their future, if they prepare for their future and if they think a lot about their future. Students were asked to indicate if they agreed to statements such as "I do lots of things to prepare for my future". Scores were summed to a scale ranging from 6 to 24 (mean $=18.95, \mathrm{SD}=2.78$, alpha $=0.63)$.

The Cronbach's Alpha of the two constructs was just below 0.70. This is probably a result of the limited variation in the responses that the students were offered. Factor analysis showed, however, that both of the constructs were unidimensional.

Entrepreneurial Intentions. Entrepreneurial intentions were captured with a yes (coded as 1) or no (coded as 0 ) question. Students were asked to indicate if they would like to start a business (mean $=0.54, \mathrm{SD}=$ 0.50). 54 percent of the students in the sample answered yes to this question. 
Control variables. In order to control for other latent constructs that previous research has shown to have an impact on entrepreneurial outcomes and educational outcomes, general attitudes towards entrepreneurship, connectedness to school and connectedness to peers were included. The latter two are often used as a proxy for school attachment (Libbey 2004). Connectedness to school is composed of six questions $($ mean $=19.39, \mathrm{SD}=2.96$, alpha $=0.77)$ that capture how students feel about their school (example question: I enjoy being at school). Connectedness to peers is also composed by six questions (mean $=20.75, \mathrm{SD}=2.86$, alpha $=0.72)$, which capture how the students get along with their classmates at school (example question: I like pretty much all of the other kids in my grade).

The students' general attitudes towards entrepreneurship were captured with a construct that McGee, Peterson, Mueller and Sequeira used in their 2009 survey. Students were asked to indicate on a four point dichotomous scale if they, in general, find entrepreneurship Worthless or Worthwhile; Disappointing or Rewarding; Negative or Positive. Scores were summed to a scale ranging from 3 to 12 $($ mean $=10.15, \mathrm{SD}=1.59$, alpha 0.77$)$.

\section{Results}

In table 2 the correlation matrix for the variables used in the analysis are presented. Because I wanted to investigate interaction effects, all variables are mean-centred. Many of the correlations between the variables are significant, indicating that they have an inter-dependent relation, but neither of the correlations is especially high. The highest correlation is found between the construct connectedness to self in the future and connectedness to school. These two constructs correlate at a 0.46 level, which indicates a strong (.40 - .69) but not very strong (> .70) relationship (Cohen, Cohen, West \& Aiken, 2003). The two educational approaches in the study, entrepreneurship education and project-based education are significantly correlated at a 0.13 level, which, however, is interpreted as a negligible relationship (ibid). The low correlation between the two educational approaches indicates that they can be compared to each other in a meaningful way. 
[Insert Table 2 here]

In table 3 the relationship between entrepreneurship education and project-based education and their effect on the personal development variable self-conception is presented in five steps.

[Insert Table 3 here]

It is clear that entrepreneurship education has a small but significant effect on students' self-conception (model 2), and that its effect remain even when project-based education enters the model (model 3). The effect of project-based education, on the other hand, is insignificant. The interaction effect between the two educational approaches (model 4) was significantly negative. In order to test if the change in explanatory power $\left(\Delta \mathrm{r}^{2}\right)$ between model 3 and model 4 was significant, an F-test was performed. The Ftest was significant on a 5 percent-level, which indicates that the interaction between entrepreneurship education and project-based education is significant and improves the explanation power of the model. The negative interaction effect only had an effect on project-based education. In order to investigate if project-based education by itself had a significant effect on students' self conception, a fifth model was constructed in which this sole effect was tested. The results in model 5, compared to model 3 and 4 , show that entrepreneurship education has a negative effect on project-based education, but project-based education does not have a negative effect on entrepreneurship education.

In the baseline model we can see that being a boy, having parents with high education, general attitudes towards entrepreneurship and school attachment, have a significant positive impact on students' self-conception. These are expected results as it has been established that females usually respond with lower values on self-esteem related scales (Marcotte, Fortin, Potvin, and Papillion 2002) and that 
socioeconomic background (Majoribanks 1996) as well as school attachment (Libbey 2004) has a positive effect on education-related variables.

In the second regression the effect of entrepreneurship education and project-based education on the personal development variable future orientation, is presented (see table 4).

[Insert Table 4 here]

The results show that entrepreneurship education has a small but significantly positive effect on students' future orientation (model 2). This effect remains when also project-based education enters the model (model 3). Project-based education has a somewhat smaller effect than entrepreneurship education, but in opposite to the previous test, it is here significant and positive. The interaction between the two educational approaches was insignificant.

Among the variables in the baseline model we can see that ethnicity and attitudes towards entrepreneurship have a small but positive effect, and that one of the school attachment variables (connectedness to school) as well as one of the work experience levels, have a fairly large impact on students' future orientation. Regarding attitudes towards entrepreneurship, this is expected in the same sense that it could be expected to be related to students' self-conception. Ethnicity turned out to be positively significant, which indicates that students with their roots in another culture prepare more for their future. Only one of the school attachment variables turned out to have a significant positive effect. This result indicates that students who have high levels of connectedness to school feel that school prepares them for their future, whereas the relationship to classmates seems only to have an effect on their present self-conception. 
In the third test, the mediating effect of the two personal development variables self-conception and future orientation, on entrepreneurial intentions, was analysed. In table 5 the results of these analyses are presented.

[Insert Table 5 here]

The results show that the effects of entrepreneurship education on entrepreneurial intentions are fully mediated by the students' level of self-conception. Neither entrepreneurship education nor project-based education has a direct effect on entrepreneurial intentions (model 2). The students' level of future orientation had a positive and significant effect (model 3), but when self-conception entered the model (model 4), this significance dropped. The effect of self-conception on entrepreneurial intentions were, however, significantly positive.

In the baseline-model we can see that being a boy, having positive general attitudes towards entrepreneurship and a father, or both parents that are self-employed, had a significantly positive effect on entrepreneurial intentions. These are all expected results that have been demonstrated in many previous surveys (see for example: Kolvereid and Isaksen 2006; Matthews and Moser 1996). It is interesting to see, though, that the entrepreneurial background of the mother did not have any effect.

Variance inflation factor tests (VIF) was performed in all three regressions to test for multicollinearity. The values ranged from 1.04 to 4.90 , well below the general rule of thumb value of 10 , which indicates that the variables passed the test on a 0.10 tolerance level (Belsley, Kuh and Welsch 1980).

In all, these three analyses show a strong support for $\mathrm{H} 1$, but only partial support for $\mathrm{H} 2$. The effects of entrepreneurship education were significantly positive on both of the personal development variables selfconception and future orientation. Project-based education did, however, only prove to have a significant effect on future orientation. H1 was thus supported as entrepreneurship education proved to have a 
stronger effect on students' personal development. H2 is only partially accepted because only one of the two personal development variables, self-conception, showed to have a significantly positive impact on entrepreneurial intentions. As it was only entrepreneurship education that had a significant effect on selfconception, this analysis shows that only entrepreneurship education has an effect, mediated by the students' level of self-conception, on entrepreneurial intentions. In figure 2 a revised theoretical model, based on the results of the analysis, is presented.

[Insert Figure 2 here]

\section{Discussion and Implications of the Results}

The following three things have been found in this research: First, at lower secondary-level of the educational system the effects of entrepreneurship education on entrepreneurial intentions are fully mediated by its effect on students' self-conception; second, entrepreneurship education has by itself an impact on students' personal development that is not only a result of its practice-based approach; third, the effect of project-based education on students' self-conception becomes insignificant if it is combined with entrepreneurship education and the interaction effect between these two educational approaches is negative. Especially the last finding has important practical implications.

Project-based education is a popular teaching method within the Danish school system. The data in our survey shows that almost all students perceive that their teachers have used this educational approach to some extent. Entrepreneurship education is another practice-based approach that has been growing in popularity during the last decades and there is currently a strong policy interest in implementing entrepreneurship education throughout the whole educational system (Löbler 2006). The positive effects of these two practice-based educational approaches do, however, become smaller when they are combined. This is a puzzling finding as the opposite could be expected given the practice-based character 
of these approaches. Due to the quantitative character of this survey, it can only be speculated about why this is the case.

It might be the case that the strong emphasis on realizing own ideas within entrepreneurship education collides with the learning goals of project-based education, which often have more strict assignment frames. This would be an effect of the different conceptualisations of experience in the two educational approaches. In the project-based approach where action and thinking is divided into different stages, experience is conceptualised as actions performed in one stage which the student reflect upon in another stage, in order to complete the final product in the closing stage. In entrepreneurship education, on the other hand, the focus is on students' own ideas and thus strongly connected to emotional experience as the problems are felt, not only cognitively thought up. This conceptualisation of experience is tightly connected to iterations and inquiries to the future. The process is not so strongly divided into stages, and failures can here be seen as opportunities for learning. The collision between these two approaches could potentially lead to lower levels of self-conception among the students, as they have to revise their world view depending on which approach they currently are subjected to. Simply put, it might be the case that the methods they learn in entrepreneurship education are conflicting with the methods they learn in project-based education. This mix of methods can possibly confuse the students and consequently have the effect that their self-conception declines.

Another reason why potentially it could be problematic to combine entrepreneurship education and project-based education is due to the practice-based character of these approaches. Both entrepreneurship education and project-based education build on the pedagogical idea of action and reflection (Schön 1983, 1987). It could be the case that students do not get enough time to reflect on their practical experiences and, thus, cannot sufficiently learn from them in a meaningful way.

This is not an argument for or against any of these approaches, rather a careful suggestion that we should be conscious of the context when we implement new educational approaches. Naturally, these results need to be replicated, but because importance of the subject and the risks involved, a precautionary 
attitude is already in order. Many of today's policy implications are based on programme evaluations that compare entrepreneurship education with "ordinary" lecture-based teaching methods. As the Danish educational system, like many other educational systems in the Western world, is fairly involved in the project-based approach, we should be careful when we impose entrepreneurship education on our students at lower levels and thoroughly analyse the students' whole educational setting.

In order to further our knowledge about the combined effect of project-based education and entrepreneurship education, a qualitative methodology has to be applied. Interviews with both students and teachers about the topic could enlighten us about how they interact and how this is perceived. In order to establish a causal effect, a longitudinal quantitative design should be used. If pre- and post-tests are applied, much of the actual impact of educational design could be established.

\section{Summary}

When entrepreneurship education and project-based education, two practice-based approaches, are combined, the effect of the latter on students' self-conception decreases. The fact that the effect of entrepreneurship education on students' self-conception remains when it is compared to project-based education indicates that it is not only the practice-based dimensions of entrepreneurship that drive the effect. It seems that it is problematic to combine two practice-based teaching methods as this ends up with "too much of two good things". Entrepreneurship education has a positive effect on both of the personal development variables future orientation and self-conception, and its effect on entrepreneurial intentions is fully mediated by the latter. Project-based education, on the other hand, has only an impact on students' level of future orientation, and, thus, no effect on entrepreneurial intentions, when compared to entrepreneurship education.

As the assignments of the educational system is changing from just providing students with knowledge to becoming a learning environment where learning is intimately intertwined with personal development, we need to pay attention to how practice-based approaches, which aims to accomplish this transition, 
affect each other. We should be conscious about the context in which we implement entrepreneurship education. It might be an idea to replace project-based education with entrepreneurship education, rather than having them running in parallel. At least, we need to make sure that two well functioning approaches, which both aim to transform the learning process within the education system, do not take out each other's positive effects due to conflicting learning goals and learning methods.

\section{References}

Albanese, M. and S. Mitchell (1993). 'Problem-Based Learning: A Review of Literature on its Outcomes and Implementation Issues'. American Medicine, 68, 52-81.

Alvarez, S.A., and J.B. Barney (2007). 'Discovery and Creation: Alternative Theories of Entrepreneurial Action'. Strategic Entrepreneurship Journal, 1 (1-2), 11-26.

Alvarez, S.A., and J.B. Barney (2010). 'Entrepreneurship and Epistemology: The Philosophical Underpinnings of the Study of Entrepreneurial Opportunities'. The Academy of Management Annals, 4 (1), 557-583.

Barber, B. K., \& J. A. Olsen (1997). 'Socialization in Context: Connection, Regulation, and Autonomy in the Family, School, and Neighborhood, and with Peers'. Journal of Adolescent Research, 12, 287-315.

Barron, B.J.S., D.L. Schwartz, N.J. Vye, A. Moore, A. Petrosino, L. Zech, J.D. Bransford (1998). 'Doing with Understanding: Lessons from Research on Problem- and Project-Based Learning'. The Journal of the Learning Science, 7 (3), $271-311$.

Baron, R. (2012). Entrepreneurship: An Evidence-Based Guide. Cheltenham, UK, Northhampton, MA, USA, Edward Elgar.

Battistich, V., D. Solomon, D. I. Kim, M. Watson, and E. Schaps (1995). 'Schools as Communities, Poverty Levels of Student Populations, and Students' Attitudes, Motives, and Performance: A Multilevel Analysis'. American Educational Research Journal, 32, 627-658.

Baumeister, R. F., and M.R., Leary (1995). 'The Need to Belong: Desire for Interpersonal Attachments as a Fundamental Human Motivation'. Psychological Bulletin, 117 (3), 497-529.

Belsley, D.A, E. Kuh, and R. E. Welsch (1980). Regression Diagnostics: Identifying Influential Data and Sources of Collinearity. New York: Wiley.

Biggs, J., and C. Tang (2007). Teaching for Quality Learning at University: What the Student Does. 3rd ed. Open University Press. McGraw Hill: Berkshire.

Cohen, J., P. Cohen, S.G. West, and L.S. Aiken (2003). Applied Multiple Regression/Correlation Analysis for the Behavioral Sciences 3rd ed., New York and London: Routledge.

Deci, E. L., R. Hodges, L. Pierson, and J. Tomassone (1992). 'Autonomy and Competence as Motivational Factors in Students with Learning Disabilities and Emotional Handicaps'. Journal of Learning Disabilities, 25, 457-471.

Demanent, J., and M. van Houtte (2012). 'School Belonging and School Misconduct: The Differing Role of Teacher and Peer Attachment'. Journal of Youth Adolescence, 41, 499-514.

Dewey, J. (1896 [1972]). 'The Reflex Arc Concept in Psychology', in Early Work 5. Ed. J.A. Boydstone. Carbondale, IL: Southern Illinois University Press, 96-109.

Dewey, J. (1916 [1980]). 'Democracy and Education: An Introduction to the Philosophy of Education', in Middle Works 9. Ed. J.A. Boydstone. Carbondale, IL: Southern Illinois University Press.

Elkær, B. (2009). 'Pragmatism: A Learning Theory for the Future' in Contemporary Theories of Learning. Ed. K. Illeris. London and New York: Routledge, 74-89.

Fayolle, A., B. Gailly, and N. Lassas-Clerc (2006). 'Assessing the Impact of Entrepreneurship Education Programmes: A New Methodology'. Journal of European Industrial Training, 30, 701-720.

Feral, C. H. (1999). Connectedness and Development: A Theory. Paper presented at the Annual Convention of the National Association of School Psychologists, New Orleans, LA.

Firestone, W. A., and S. Rosenblum (1988). 'Building Commitment in Urban High Schools'. Educational Evaluation and Policy Analysis, 10, 285-299.

Foss, N.J., and P.G. Klein (2012). Organizing Entrepreneurial Judgment: A New Approach to the Firm. New York: Cambridge University Press.

Gibb, A.A. (1987). 'Designing Effective Programmes for Encouraging and Supplying the Business Start-Up Process: Lessons from UK Experience', Journal of European Industrial Training, 11 (4), 24-32. 
Gibb, A.A. (2002). 'In Pursuit of a New Entrepreneurship Paradigm for Learning: Creative Destruction, New Values, New Ways of Doing Things and New Combinations of Knowledge'. International Journal of Management Reviews, 4 (3), $233-69$.

Hirschi, T. (1969). Causes of delinquency. Berkeley: University of California Press.

Honig, B. (2004). 'Entrepreneurship Education: Toward a Model of Contingency-Based Business Planning'. Academy of Management Learning and Education, 3(3), 258-273.

Illeris, K. (2003). 'Learning, Identity and Self-Orientation in Youth'. Young - Nordic Journal of Youth Research, 11 (4), $357-76$.

Illeris, K. (2009). 'A Comprehensive Understanding of Human Learning', in Contemporary Theories of Learning, ed. K. Illeris. London and New York: Routledge, 7-20.

Jarvis, P. (2009). 'Learning to Be a Person in Society', in Contemporary Theories of Learning, ed. K. Illeris. London and New York: Routledge, 20-34.

Jimerson, S.R., E. Campos, and J.L. Greif (2003). 'Toward an Understanding of Definitions and Measures of School Engagement and Related Terms'. The California School Psychologist, 8,7-27.

Johannisson, B. 1991. University training for entrepreneurship: Swedish approaches. Entrepreneurship and Regional development, 3(1), 67-82.

Karcher, M.J. (2001). Measuring Adolescent Connectedness: Four Validation Studies. Poster presented at the annual convention of the American Psychological Association, San Francisco, CA.

Karcher, M.J. (2003). The Hemingway Measure of Adolescent Connectedness. Connectedness Report: Small Rural School District. March 22, 2003.

Karcher, M.J., and , J. Lindwall (2003). 'Social Interest, Connectedness, and Challenging Experiences: What Makes High School Mentors Persist'. Journal of Individual Psychology, 59 (3), 293-315.

Katz, J.A. (1995). 'Managing Practitioners in the Entrepreneurship Class'. Simulation and Gaming 26(3), 361-375.

Katz, J.A. (2003). 'The Chronology and Intellectual Trajectory of American Entrepreneurship Education'. Journal of Business Venturing 18, 283-300.

Katz, J.A. (2008). 'Fully Mature but Not Fully Legitimate: A Different Perspective on the State of Entrepreneurship Education'. Journal of Small Business Management, 46(4), 550-566

Knudsen, S.V. (1999). Projektarbejdets Fortid og Fremtid. København: Denmarks Lærerhøjskole.

Kolb, D.A. (1984). Experiential Learning: Experience as the Source of Learning and Development. Englewood Cliffs, NJ: Prentice-Hall.

Kolvereid, L., and E. Isaksen (2006). 'New Business Start-Up and Subsequent Entry into Self-Employment. Journal of Business Venturing 21, 866-885.

Kyrö P. and M. Niemi (2007). 'Advancing Business Planning -From Planning to Entrepreneurial Learning', in Twente case studybook. Ed. Blauen G.

Lee, R. M., and S. B. Robbins (1995). 'Measuring Belongingness: The Social Connectedness and the Social Assurance Scales'. Journal of Counseling Psychology, 42 (2), 232-241.

Libbey, H. P. (2004). 'Measuring Student Relationships to School: Attachment, Bonding, Connectedness, and Engagement'. Journal of School Health, 74, 274-283.

Loyens, S.M.M., J. Magda, and R.M.J.P. Rikers (2008). 'Self-Directed Learning in Problem-Based Learning and its Relationship with Self-Regulated Learning'. Educ Psychol Rev, 20, 411-427

Löbler, H. (2006). 'Learning Entrepreneurship from a Constructivist Perspective'. Technology Analysis \& Strategic Management, $18(1), 19-38$.

Majoribanks, K. (1996). 'Family Learning Environments and Students' Outcomes: A Review'. Journal of Comparative Family Studies, 27(2), 373-394.

Marcotte, D., L. Fortin, P. Potvin, and M. Papillion (2002). 'Gender Differences in Depressive Symptoms During Adolescence: Role of Gender-Typed Characteristics, Self-Esteem, Body Image, Stressful Life Events, and Pubertal Status'. Journal of Emotional \& Behavioral Disorders, 10 (1), 29-43.

Mason, L. H. (2004). 'Explicit Self-Regulated Strategy Development versus Reciprocal Questioning: Effects on Expository Reading Comprehension Among Struggling Readers'. Journal of Educational Psychology, 96, 283-296.

Matthews, C.H., and S.B. Moser (1996).' A Longitudinal Investigation of the Impact of Family Background and Gender on Interest in Small Firm Ownership'. Journal of Small Business Management, 34(2), 29-43.

McGee, J. E., M. Peterson, S.L. Mueller, and J.M. Sequeira. (2009). Entrepreneurial Self-Efficacy: Refining the Measure'. Entrepreneurship Theory and Practice, 33(4).

McKay, J., and D. Kember (1997). 'Spoon Feeding Leads to Regurgitation: A Better Diet can Result in More Digestible Learning Outcomes'. Higher Education Research and Development, 16, 55-68.

McMullen, J.S., and D.A. Shepherd (2006). 'Entrepreneurial Action and the Role of Uncertainty in the Theory of the Entrepreneur'. Academy of Management Review, 31 (1), 132-152.

Minnaert, A., and Janssen, P. J. (1999). 'The Additive Effect of Regulatory Activities on Top of Intelligence in Relation to Academic Performance in Higher Education. Learning and Instruction, 9, 77-91.

Nakkula, M., C. Pineda, A. Dray, and M. Lutyens (2003). Expanded explorations into the psychology of entrepreneurship: Findings from the 2001-2002 study of NFTE in two Boston public high-schools. Harvard University Graduate School of Education. 
Nakkula, M., M. Lutyens, C. Pineda, A. Dray, F. Gaytan, and J. Hugulay (2004). Initiating, Leading, and Feeling in Control of One's Fate: Findings from the 2002-2003 Study of NFTE in Six Boston Public High Schools. Harvard University Graduate School of Education.

Nunnally, J. (1978). Psychometric Theory, 3d ed. New York: McGraw-Hill.

Peterman, N., and J. Kennedy (2003). 'Enterprise Education: Influencing Students' Perceptions of Entrepreneurship'. Entrepreneurship Theory and Practice, 28, 129-144.

Politis, D. 2005. Entrepreneurship, Career Experience and Learning: Developing our Understanding of Entrepreneurship as an Experiential Learning Process, PhD Dissertation. Lund University.

Rossiter, J.R. 2002. 'The C-OAR-SE Procedure for Scale Development in Marketing'. International Journal of Research in Marketing, 19, 305-335.

Sarasvathy, S.D. (2004). 'Making it Happen: Beyond Theories of the Firm to Theories of Firm Design'. Entrepreneurship Theory \& Practice, 28 (6), 519-531.

Sarasvathy, S. (2008). Effectuation: Elements of Entrepreneurial Expertise. UK, Cheltenham: Edward Elgar Publishing Limited

Sarasvathy, S. D., and S. Venkataraman (2011). Entrepreneurship as Method: Open Questions for an Entrepreneurial Future. Entrepreneurship Theory and Practice, 35(1), 113-135.

Schön, D.A. (1983). The Reflective Practitioner: How Professionals Think in Action. London: Maurice Temple Smith.

Schön, D.A. (1987). Educating the Reflective Practitioner. San Francisco, CA: Jossey-Bass.

Shepherd, D. (2004). 'Educating Entrepreneurship Students About Emotion and Learning From Failure'. Academy of Management Learning and Education 3 (3), 274-287.

Souitaris, V., S. Zerbinati, and A. Al-Laham (2007). 'Do Entrepreneurship Programmes Raise Entrepreneurial Intention of Science and Engineering Students?: The Effect of Learning, Inspiration and Resources. Journal of Business Venturing, 22, $566-591$.

\section{Online sources}

www.ffe-ye.dk 01-07-2012 
Figure 1

Theoretical Model

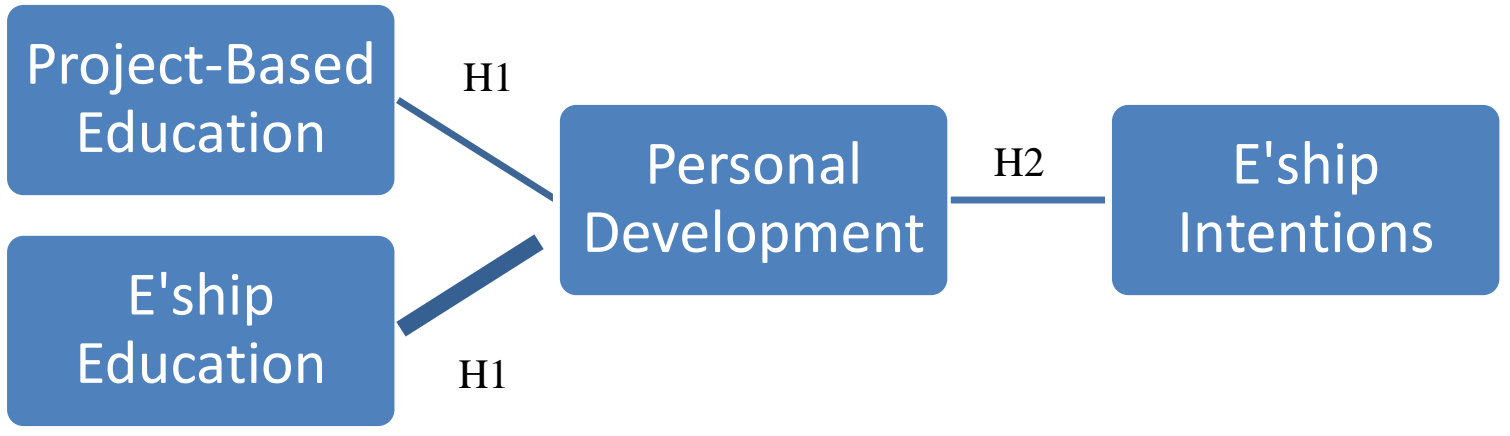

Figure 2:

Revised Theoretical Model

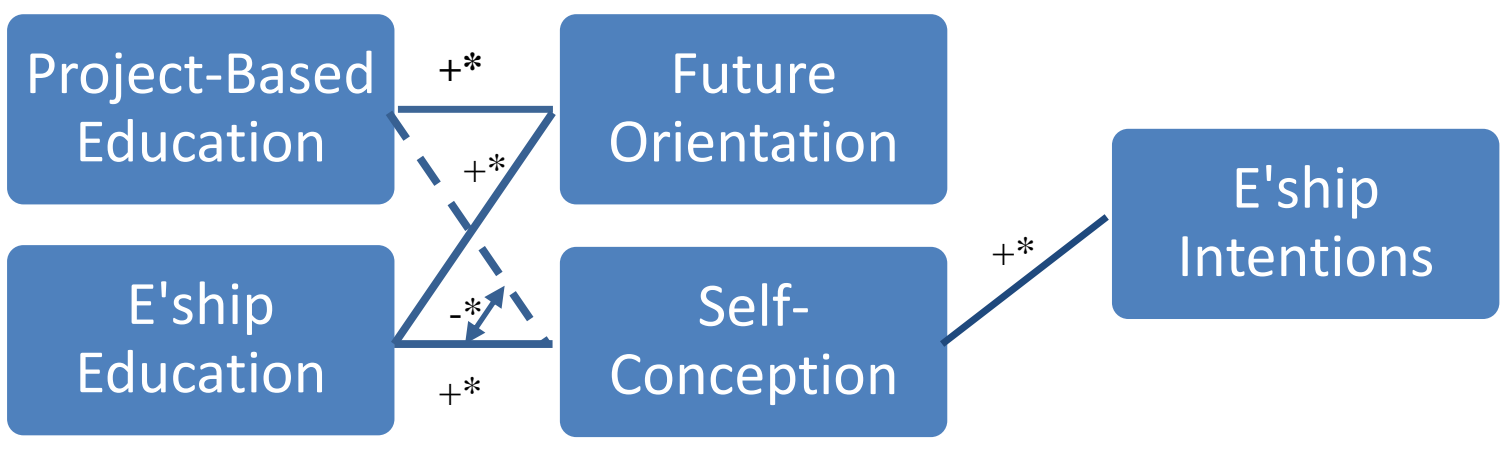


Table 1

Descriptive Statistics

\begin{tabular}{|c|c|c|c|c|}
\hline Variable names & Mean & Percent. & Std. & Range/info \\
\hline Project-Based Education & 3,200 & & 0,8431 & $1-4$ \\
\hline $\begin{array}{l}\text { Entrepreneurship Education } \\
\text { Gender }\end{array}$ & 1,722 & & 0,8392 & $1-4$ \\
\hline - $\quad$ Female & & 53,04 & & 0 \\
\hline Male & & 46,96 & & 1 \\
\hline Ethnicity & & 23,48 & & $0-1$ \\
\hline Parents education level & & & & \\
\hline$-\quad$ University & & 24,59 & & 4 \\
\hline - Professional bachelor & & 38,12 & & 3 \\
\hline - $\quad$ Academy profession & & 25,00 & & 2 \\
\hline - Upper scondary & & 6,35 & & 1 \\
\hline - Basis school & & 5,94 & & Baseline \\
\hline Parents self-employed & & & & \\
\hline - Both & & 5,52 & & 3 \\
\hline - Dad & & 15,19 & & 2 \\
\hline - Mom & & 4,56 & & 1 \\
\hline - No & & 74,72 & & Baseline \\
\hline Work experience & & & & \\
\hline - $\quad$ Yes ( $\geq 2$ days/week) & & 33,70 & & 4 \\
\hline - $\quad$ Yes ( 1 day/week) & & 14,92 & & 3 \\
\hline - $\quad$ Yes (<1 day/month) & & 5,66 & & 2 \\
\hline - Yes (only in vacations) & & 4,28 & & 1 \\
\hline - $\quad$ No work & & 41,44 & & Baseline \\
\hline Attitudes $($ alpha $=0,77)$ & 10,14 & & 0,0591 & $3-12$ \\
\hline School $($ alpha $=0,77)$ & 19,39 & & 0,1099 & $6-24$ \\
\hline Classmates $($ alpha $=\mathbf{0 , 7 2})$ & 20,75 & & 0,1061 & $6-24$ \\
\hline Self-conception (alpha $=0,67)$ & 19,06 & & 0,1117 & $6-24$ \\
\hline Future $($ alpha $=0,63)$ & 18,95 & & 0,1034 & $6-24$ \\
\hline Intentions & 0,536 & & 0,0185 & $0-1$ \\
\hline
\end{tabular}


Table 2

Correlation Matrix

\begin{tabular}{|c|c|c|c|c|c|c|c|c|c|c|c|c|c|}
\hline Project Edu. & $\begin{array}{l}\text { Project } \\
\text { Edu. } \\
\end{array}$ & $\begin{array}{l}\text { E'ship } \\
\text { Edu. }\end{array}$ & Gender & Ethnicity & Education & Entre. & $\begin{array}{l}\text { Work } \\
\text { exp. }\end{array}$ & Attitudes & School & Peers & Self-con. & Future & Intension \\
\hline E'ship Edu. & $\begin{array}{r}0,1343 \\
(0,0002)\end{array}$ & 1 & & & & & & & & & & & \\
\hline Gender & $\begin{array}{r}0,0095 \\
(0,7976)\end{array}$ & $\begin{array}{r}-0,0185 \\
(0,6191)\end{array}$ & 1 & & & & & & & & & & \\
\hline Ethnicity & $\begin{array}{r}0,0230 \\
(0,5362)\end{array}$ & $\begin{array}{r}0,0085 \\
(0,8187)\end{array}$ & $\begin{array}{r}0,0141 \\
(0,7041)\end{array}$ & 1 & & & & & & & & & \\
\hline Education & $\begin{array}{r}0,1231 \\
(0,0009)\end{array}$ & $\begin{array}{r}-0,0773 \\
(0,0375)\end{array}$ & $\begin{array}{r}0,0259 \\
(0,4870)\end{array}$ & $\begin{array}{r}0,0107 \\
(0,7728)\end{array}$ & 1 & & & & & & & & \\
\hline Entrepreneur & $\begin{array}{r}-0,0099 \\
(0,7895)\end{array}$ & $\begin{array}{r}-0,0078 \\
(0,8344)\end{array}$ & $\begin{array}{r}0,0025 \\
(0,9474)\end{array}$ & $\begin{array}{r}-0,0540 \\
(0,1468)\end{array}$ & $\begin{array}{r}0,0706 \\
(0,0577)\end{array}$ & 1 & & & & & & & \\
\hline Work exp. & $\begin{array}{r}-0,0110 \\
(0,7677)\end{array}$ & $\begin{array}{r}-0,0274 \\
(0,4620)\end{array}$ & $\begin{array}{r}-0,1139 \\
(0,0021)\end{array}$ & $\begin{array}{r}-0,1072 \\
(0,0039)\end{array}$ & $\begin{array}{r}-0,0410 \\
(0,2708)\end{array}$ & $\begin{array}{r}0,0247 \\
(0,5076)\end{array}$ & 1 & & & & & & \\
\hline Attitudes & $\begin{array}{r}0,1351 \\
(0,0003)\end{array}$ & $\begin{array}{r}0,0675 \\
(0,0695)\end{array}$ & $\begin{array}{r}-0,0162 \\
(0,6633)\end{array}$ & $\begin{array}{r}-0,1387 \\
(0,0002)\end{array}$ & $\begin{array}{r}0,1223 \\
(0,0010)\end{array}$ & $\begin{array}{r}0,0609 \\
(0,1018)\end{array}$ & $\begin{array}{r}0,0870 \\
(0,0192)\end{array}$ & 1 & & & & & \\
\hline School & $\begin{array}{r}0,1979 \\
(0,0000)\end{array}$ & $\begin{array}{r}0,0684 \\
(0,0659)\end{array}$ & $\begin{array}{r}-0,1343 \\
(0,0003)\end{array}$ & $\begin{array}{r}0,0510 \\
(0,1706)\end{array}$ & $\begin{array}{r}0,0551 \\
(0,1384)\end{array}$ & $\begin{array}{r}0,0143 \\
(0,7014)\end{array}$ & $\begin{array}{r}0,0503 \\
(0,1762)\end{array}$ & $\begin{array}{r}0,1953 \\
(0,0000)\end{array}$ & 1 & & & & \\
\hline Peers & $\begin{array}{r}0,1555 \\
(0,0000)\end{array}$ & $\begin{array}{r}0,0405 \\
(0,2763)\end{array}$ & $\begin{array}{r}-0,0214 \\
(0,5655)\end{array}$ & $\begin{array}{r}-0,0411 \\
(0,2689)\end{array}$ & $\begin{array}{r}0,0681 \\
(0,0671)\end{array}$ & $\begin{array}{r}-0,0153 \\
(0,6813)\end{array}$ & $\begin{array}{r}0,0444 \\
(0,2323)\end{array}$ & $\begin{array}{r}0,1999 \\
(0,0000)\end{array}$ & $\begin{array}{r}0,3837 \\
(0,0000)\end{array}$ & 1 & & & \\
\hline Self-con. & $\begin{array}{r}0,1804 \\
(0,0000)\end{array}$ & $\begin{array}{r}0,1108 \\
(0,0028)\end{array}$ & $\begin{array}{r}0,1280 \\
(0,0006)\end{array}$ & $\begin{array}{r}0,0564 \\
(0,1297)\end{array}$ & $\begin{array}{r}0,2077 \\
(0,0000)\end{array}$ & $\begin{array}{r}0,0138 \\
(0,7111)\end{array}$ & $\begin{array}{r}-0,0642 \\
(0,0841)\end{array}$ & $\begin{array}{r}0,2097 \\
(0,0000)\end{array}$ & $\begin{array}{r}0,3474 \\
(0,0000)\end{array}$ & $\begin{array}{r}0,2631 \\
(0,0000)\end{array}$ & 1 & & \\
\hline Future & $\begin{array}{r}0,1999 \\
(0,0000)\end{array}$ & $\begin{array}{r}0,1411 \\
(0,0001)\end{array}$ & $\begin{array}{r}-0,0523 \\
(0,1596)\end{array}$ & $\begin{array}{r}0,0671 \\
(0,0714)\end{array}$ & $\begin{array}{r}0,0465 \\
(0,2109)\end{array}$ & $\begin{array}{r}-0,0406 \\
(0,2748)\end{array}$ & $\begin{array}{r}0,1129 \\
(0,0023)\end{array}$ & $\begin{array}{r}0,2463 \\
(0,0000)\end{array}$ & $\begin{array}{r}0,4583 \\
(0,0000)\end{array}$ & $\begin{array}{r}0,1861 \\
(0,0000)\end{array}$ & $\begin{array}{r}0,4000 \\
(0,0000)\end{array}$ & 1 & \\
\hline Intensions & $\begin{array}{r}0,0174 \\
(0,6402)\end{array}$ & $\begin{array}{r}0,0057 \\
(0,8789\end{array}$ & $\begin{array}{r}0,0932 \\
(0,0121)\end{array}$ & $\begin{array}{l}-0,0072 \\
(0,8462\end{array}$ & $\begin{array}{r}0,0611 \\
(0,1006)\end{array}$ & $\begin{array}{r}0,1239 \\
(0,0008)\end{array}$ & $\begin{array}{r}0,0647 \\
(0,0819)\end{array}$ & $\begin{array}{r}0,1354 \\
(0,0003)\end{array}$ & $\begin{array}{r}0,0449 \\
(0,2274)\end{array}$ & $\begin{array}{r}0,0204 \\
(0,5828)\end{array}$ & $\begin{array}{l}0,1685 \\
(0,000)\end{array}$ & $\begin{array}{r}0,1243 \\
(0,0008)\end{array}$ & 1 \\
\hline
\end{tabular}


Table 3

Effects of Entrepreneurship Education and Project-Based Education on Students' Self-Conception

\begin{tabular}{|c|c|c|c|c|c|c|c|c|c|c|}
\hline \multirow[t]{2}{*}{ Variable names } & \multicolumn{2}{|c|}{ Model 1} & \multicolumn{2}{|c|}{ Model 2} & \multicolumn{2}{|c|}{ Model 3} & \multicolumn{2}{|c|}{ Model 4} & \multicolumn{2}{|c|}{ Model 5} \\
\hline & Coef. & Std. & Coef. & Std. & Coef. & Std. & Coef. & Std. & Coef. & Std. \\
\hline Gender (Male) & 0,1648 *** & 0,0341 & $0,1664 * * *$ & 0,0334 & $0,1647 * * *$ & 0,0339 & $0,1644 * * *$ & 0,0339 & $0,1625 * * *$ & 0,0341 \\
\hline Ethnicity & 0,0698 & 0,0407 & 0,0684 & 0,0405 & 0,0670 & 0,0405 & 0,0617 & 0,0405 & 0,0680 & 0,0407 \\
\hline \multicolumn{11}{|l|}{ Education } \\
\hline-2 & $-0,0124$ & 0,0956 & 0,0034 & 0,0953 & $-0,0117$ & 0,0957 & $-0,0055$ & 0,0955 & $-0,0294$ & 0,0958 \\
\hline 3 & $0,1708 * *$ & 0,0770 & $0,1868 * *$ & 0,0768 & $0,1705^{* *}$ & 0,0774 & $0,1780 * *$ & 0,0773 & 0,1524 & 0,0774 \\
\hline 4 & $0,2262 * * *$ & 0,0747 & $0,2443 * * *$ & 0,0746 & $0,2301 * *$ & 0,0750 & $0,2350 * *$ & 0,0749 & 0,2106 & 0,0750 \\
\hline 5 & $0,2863 * * *$ & 0,0769 & $0,3084 * * *$ & 0,0770 & $0,2889 * * *$ & 0,0778 & $0,2886 * * *$ & 0,0776 & 0,2645 & 0,0776 \\
\hline \multicolumn{11}{|l|}{ Entrepreneur } \\
\hline-2 & $-0,0449$ & 0,0812 & $-0,0497$ & 0,0808 & $-0,0396$ & 0,0810 & $-0,0357$ & 0,0808 & $-0,0330$ & 0,0813 \\
\hline 3 & $-0,0336$ & 0,0469 & $-0,0303$ & 0,0467 & $-0,0296$ & 0,0467 & $-0,0278$ & 0,0465 & $-0,0324$ & 0,0468 \\
\hline 4 & $-0,0242$ & 0,0740 & $-0,0266$ & 0,0736 & $-0,0250$ & 0,0735 & $-0,0219$ & 0,0734 & $-0,0224$ & 0,0738 \\
\hline \multicolumn{11}{|l|}{ Work experience } \\
\hline-1 & $-0,0963$ & 0,0843 & $-0,1047$ & 0,0840 & $-0,0984$ & 0,840 & $-0,1027$ & 0,0838 & $-0,0985$ & 0,0842 \\
\hline 2 & 0,0329 & 0,0750 & 0,0445 & 0,0748 & 0,0462 & 0,0747 & 0,0479 & 0,0745 & 0,0360 & 0,0749 \\
\hline 3 & $-0,0787$ & 0,0507 & $-0,0703$ & 0,0505 & $-0,0718$ & 0,0505 & $-0,0665$ & 0,0504 & $-0,0797$ & 0,0506 \\
\hline-4 & $-0,0696$ & 0,0391 & $-0,0675$ & 0,0389 & $-0,0655$ & 0,090 & $-0,0656$ & 0,0388 & $-0,0672$ & 0,0390 \\
\hline Attitudes & $0,0392 * * *$ & 0,0110 & $0,0371 * *$ & 0,0109 & $0,0358 * *$ & 0,0110 & $0,0368 * *$ & 0,0109 & 0,0374 & 0,0110 \\
\hline School & $0,2941 * * *$ & 0,0379 & $0,2892 * * *$ & 0,0371 & $0,2809 * * *$ & 0,0375 & $0,2810 * * *$ & 0,0374 & 0,2834 & 0,0376 \\
\hline Peers & $0,1342 * * *$ & 0,0383 & $0,1327 * *$ & 0,0382 & $0,1285^{* *}$ & 0,0382 & $0,1240 * *$ & 0,0382 & 0,1290 & 0,0384 \\
\hline E'ship Edu. & & & $0,0563 * *$ & 0,0199 & $0,0518 * *$ & 0,0201 & $0,0564 * *$ & 0,0202 & & \\
\hline Project-Based Edu. & & & & & 0,0332 & 0,0206 & 0,0297 & 0,0206 & $0,0407^{*}$ & 0,0205 \\
\hline E'ship*PBE & & & & & & & $-0,0520^{*}$ & 0,0242 & & \\
\hline Cons & $-0,2463$ & 0,0761 & $-0,2667$ & 0,0760 & $-0,2517$ & 0,0765 & $-0,2506$ & 0,0763 & $-0,2299$ & 0,0763 \\
\hline Num. Obs. & 724 & & 724 & & 724 & & 724 & & 724 & \\
\hline F value & 12,91 & & 12,74 & & 12,21 & & 11,87 & & 12,44 & \\
\hline - $\quad$ Prob. & 0,0000 & & 0,0000 & & 0,0000 & & 0,0000 & & 0,0000 & \\
\hline R-squared adj. & 0,2086 & & 0,2164 & & 0,2181 & & 0,2221 & & 0,2119 & \\
\hline
\end{tabular}

Table 4

Effects of Entrepreneurship Education and Project-Based Education on Students' Future Orientation

\begin{tabular}{|c|c|c|c|c|c|c|}
\hline \multirow[t]{2}{*}{ Variable names } & \multicolumn{2}{|c|}{ Model 1} & \multicolumn{2}{|c|}{ Model 2} & \multicolumn{2}{|r|}{ Model 3} \\
\hline & Coef. & Std. & Coef. & Std. & Coef. & Std. \\
\hline Gender (Male) & 0,0111 & 0,0309 & 0,0131 & 0,0307 & 0,0101 & 0,0306 \\
\hline Ethnicity & $0,0838 *$ & 0,0369 & $0,0824 *$ & 0,0367 & $0,0805^{*}$ & 0,0366 \\
\hline \multicolumn{7}{|l|}{ Education } \\
\hline-2 & 0,1213 & 0,0867 & 0,1376 & 0,0863 & 0,1162 & 0,0864 \\
\hline 3 & 0,0638 & 0,0698 & 0,0804 & 0,0695 & 0,0574 & 0,0699 \\
\hline 4 & 0,0584 & 0,0677 & 0,0771 & 0,0675 & 0,0571 & 0,0677 \\
\hline 5 & 0,0732 & 0,0697 & 0,0960 & 0,0696 & 0,0684 & 0,0702 \\
\hline \multicolumn{7}{|l|}{ Entrepreneur } \\
\hline-2 & $-0,0057$ & 0,0736 & $-0,0106$ & 0,0731 & 0,0036 & 0,0731 \\
\hline 3 & $-0,0818$ & 0,0425 & $-0,0784$ & 0,0423 & $-0,0774$ & 0,0421 \\
\hline-4 & $-0,0477$ & 0,0671 & $-0,0501$ & 0,0666 & $-0,0478$ & 0,0664 \\
\hline \multicolumn{7}{|l|}{ Work experience } \\
\hline-1 & 0,0013 & 0,0765 & $-0,0073$ & 0,0760 & 0,0015 & 0,0758 \\
\hline 2 & 0,0510 & 0,0680 & 0,0630 & 0,0677 & 0,0654 & 0,0674 \\
\hline 3 & $-0,0076$ & 0,0460 & 0,0009 & 0,0457 & $-0,0011$ & 0,0456 \\
\hline-4 & $0,1055^{*}$ & 0,0355 & $0,1079 * *$ & 0,035 & $0,1108 * *$ & 0,035 \\
\hline Attitudes & $0,0500 * * *$ & 0,0100 & $0,0479 * * *$ & 0,0099 & $0,0460 * * *$ & 0,0099 \\
\hline School & $0,3983 * * *$ & 0,0338 & $0,3933 * * *$ & 0,0336 & 0,3815 *** & 0,0338 \\
\hline Peers & $-0,0165$ & 0,0348 & $-0,0181$ & 0,0346 & $-0,0240$ & 0,0345 \\
\hline E'ship Edu. & & & $0,0582 * *$ & 0,0180 & $0,0517 * *$ & 0,0182 \\
\hline Project-Based Edu. & & & & & $0,0469 *$ & 0,0186 \\
\hline Cons. & $-0,1109$ & 0,0689 & $-0,1320$ & 0,0689 & $-0,1107$ & 0,0691 \\
\hline Num. Obs. & 724 & & 724 & & 724 & \\
\hline F value & 15,34 & & 15,24 & & 14,86 & \\
\hline - $\quad$ Prob. & 0,0000 & & 0,0000 & & 0,0000 & \\
\hline R-square adj. & 0,2409 & & 0,2509 & & 0,2565 & \\
\hline
\end{tabular}


Table 5

The Mediating Effect Self-Conception and Future Orientation on Entrepreneurial Intentions

\begin{tabular}{|c|c|c|c|c|c|c|c|c|}
\hline \multirow[t]{2}{*}{ Variable names } & \multicolumn{2}{|c|}{ Model 1} & \multicolumn{2}{|c|}{ Model 2} & \multicolumn{2}{|c|}{ Model 3} & \multicolumn{2}{|c|}{ Model 4} \\
\hline & Coef. & Std. & Coef. & Std. & Coef. & Std. & Coef. & Std. \\
\hline Gender (Male) & $0,4376^{* *}$ & 0,1584 & $0,4393 * *$ & 0,1586 & $0,4373 * *$ & 0,1593 & $0,3430 *$ & 0,1627 \\
\hline Ethnicity & 0,0362 & 0,1885 & 0,0376 & 0,1886 & $-0,0042$ & 0,1902 & $-0,0278$ & 0,1920 \\
\hline \multicolumn{9}{|l|}{ Education } \\
\hline-2 & 0,2043 & 0,4421 & 0,2159 & 0,4441 & 0,1625 & 0,4460 & 0,1901 & 0,4484 \\
\hline 3 & $-0,0829$ & 0,3555 & $-0,0701$ & 0,3585 & $-0,0996$ & 0,3600 & $-0,1899$ & 0,3627 \\
\hline 4 & $-0,0326$ & 0,03447 & $-0,0217$ & 0,3470 & $-0,0494$ & 0,3483 & $-0,1777$ & 0,3523 \\
\hline 5 & 0,3297 & 0,3570 & 0,3450 & 0,3614 & 0,3149 & 0,3625 & 0,1588 & 0,3671 \\
\hline \multicolumn{9}{|l|}{ Entrepreneur } \\
\hline-2 & $-0,2195$ & 0,3718 & $-0,2274$ & 0,3728 & $-0,2309$ & 0,3756 & $-0,2084$ & 0,3790 \\
\hline 3 & $0,4316^{*}$ & 0,2199 & $0,4312 *$ & 0,2199 & $0,4741^{*}$ & 0,2220 & $0,4848 *$ & 0,2239 \\
\hline 4 & $0,9989 * *$ & 0,3850 & $0,9971 * *$ & 0,3850 & $1,036 * *$ & 0,3879 & $1,068 * *$ & 0,3915 \\
\hline \multicolumn{9}{|l|}{ Work experience } \\
\hline-1 & 0,2981 & 0,3912 & 0,2934 & 0,3916 & 0,2995 & 0,3935 & 0,3776 & 0,4000 \\
\hline 2 & 0,4287 & 0,3469 & 0,4277 & 0,3470 & 0,3987 & 0,3498 & 0,3940 & 0,3538 \\
\hline 3 & 0,1625 & 0,2342 & 0,1637 & 0,2343 & 0,1641 & 0,2360 & 0,2095 & 0,2382 \\
\hline 4 & 0,3354 & 0,1816 & 0,3341 & 0,1817 & 0,2813 & 0,1833 & 0,3554 & 0,1857 \\
\hline Attitudes & $0,1654 * *$ & 0,0516 & $0,1664 * *$ & 0,0517 & 0,1447 ** & 0,0525 & $0,1339 *$ & 0,0530 \\
\hline Peers & $-0,0636$ & 0,1783 & $-0,0605$ & 0,1787 & $-0,0493$ & 0,1793 & $-0,1317$ & 0,1831 \\
\hline School & 0,1345 & 0,1729 & 0,1411 & 0,1746 & $-0,0541$ & 0,1909 & $-0,1577$ & 0,1956 \\
\hline E'ship Edu. & 0,0087 & 0,0926 & 0,0122 & 0,0935 & $-0,0135$ & 0,0945 & $-0,0349$ & 0,0953 \\
\hline $\begin{array}{l}\text { Project-Based } \\
\text { Edu. }\end{array}$ & & & $-0,0259$ & 0,0960 & $-0,0504$ & 0,0970 & $-0,0644$ & 0,0980 \\
\hline Future & & & & & $0,5123^{* *}$ & 0,1967 & 0,3387 & 0,2052 \\
\hline Self-conception & & & & & & & $0,6036 * *$ & 0,1873 \\
\hline Cons. & $-0,4046$ & 0,3519 & $-0,4165$ & 0,3546 & $-0,3649$ & 0,3563 & $-0,2405$ & 0,3600 \\
\hline Num. Obs. & 724 & & 724 & & 724 & & 724 & \\
\hline LR chi2 & 41,72 & & 41,80 & & 48,66 & & 59,30 & \\
\hline - $\quad$ Prob. & 0,0007 & & 0,0012 & & 0,0002 & & 0,0000 & \\
\hline Pseudo R-square & 0,0417 & & 0,0418 & & 0,0487 & & 0,0593 & \\
\hline
\end{tabular}

$*<0,05 \quad * *<0,01 \quad * * *<0,001$ 


\section{SMG - Working Papers \\ www.cbs.dk/smg \\ 2003}

2003-1: Nicolai J. Foss, Kenneth Husted, Snejina Michailova, and Torben Pedersen: Governing Knowledge Processes: Theoretical Foundations and Research Opportunities.

2003-2: Yves Doz, Nicolai J. Foss, Stefanie Lenway, Marjorie Lyles, Silvia Massini, Thomas P. Murtha and Torben Pedersen: Future Frontiers in International Management Research: Innovation, Knowledge Creation, and Change in Multinational Companies.

2003-3: Snejina Michailova and Kate Hutchings: The Impact of In-Groups and OutGroups on Knowledge Sharing in Russia and China CKG Working Paper.

2003-4: Nicolai J. Foss and Torben Pedersen: The MNC as a Knowledge Structure: The Roles of Knowledge Sources and Organizational Instruments in MNC Knowledge Management CKG Working Paper.

2003-5: Kirsten Foss, Nicolai J. Foss and Xosé H. Vázquez-Vicente: “Tying the Manager's Hands": How Firms Can Make Credible Commitments That Make Opportunistic Managerial Intervention Less Likely CKG Working Paper.

2003-6: Marjorie Lyles, Torben Pedersen and Bent Petersen: Knowledge Gaps: The Case of Knowledge about Foreign Entry.

2003-7: Kirsten Foss and Nicolai J. Foss: The Limits to Designed Orders: Authority under "Distributed Knowledge" CKG Working Paper.

2003-8: Jens Gammelgaard and Torben Pedersen: Internal versus External Knowledge Sourcing of Subsidiaries - An Organizational Trade-Off.

2003-9: Kate Hutchings and Snejina Michailova: Facilitating Knowledge Sharing in Russian and Chinese Subsidiaries: The Importance of Groups and Personal Networks Accepted for publication in Journal of Knowledge Management.

2003-10: Volker Mahnke, Torben Pedersen and Markus Verzin: The Impact of Knowledge Management on MNC Subsidiary Performance: the Role of Absorptive Capacity CKG Working Paper.

2003-11: Tomas Hellström and Kenneth Husted: Mapping Knowledge and Intellectual Capital in Academic Environments: A Focus Group Study Accepted for publication in Journal of Intellectual Capital CKG Working Paper.

2003-12: Nicolai J Foss: Cognition and Motivation in the Theory of the Firm: Interaction or "Never the Twain Shall Meet"? Accepted for publication in Journal des Economistes et des Etudes Humaines CKG Working Paper.

2003-13: Dana Minbaeva and Snejina Michailova: Knowledge Transfer and Expatriation Practices in MNCs: The Role of Disseminative Capacity.

2003-14: Christian Vintergaard and Kenneth Husted: Enhancing Selective Capacity Through Venture Bases. 


\section{4}

2004-1: Nicolai J. Foss: Knowledge and Organization in the Theory of the Multinational Corporation: Some Foundational Issues

2004-2: Dana B. Minbaeva: HRM Practices and MNC Knowledge Transfer

2004-3: Bo Bernhard Nielsen and Snejina Michailova: Toward a Phase-Model of Global Knowledge Management Systems in Multinational Corporations

2004-4: Kirsten Foss \& Nicolai J Foss: The Next Step in the Evolution of the RBV: Integration with Transaction Cost Economics

2004-5: Teppo Felin \& Nicolai J. Foss: Methodological Individualism and the Organizational Capabilities Approach

2004-6: Jens Gammelgaard, Kenneth Husted, Snejina Michailova: Knowledge-sharing Behavior and Post-acquisition Integration Failure

2004-7: Jens Gammelgaard: Multinational Exploration of Acquired R\&D Activities

2004-8: Christoph Dörrenbächer \& Jens Gammelgaard: Subsidiary Upgrading? Strategic Inertia in the Development of German-owned Subsidiaries in Hungary

2004-9: Kirsten Foss \& Nicolai J. Foss: Resources and Transaction Costs: How the Economics of Property Rights Furthers the Resource-based View

2004-10: Jens Gammelgaard \& Thomas Ritter: The Knowledge Retrieval Matrix: Codification and Personification as Separate Strategies

2004-11: Nicolai J. Foss \& Peter G. Klein: Entrepreneurship and the Economic Theory of the Firm: Any Gains from Trade?

2004-12: Akshey Gupta \& Snejina Michailova: Knowledge Sharing in Knowledge-Intensive Firms: Opportunities and Limitations of Knowledge Codification

2004-13: Snejina Michailova \& Kate Hutchings: Knowledge Sharing and National Culture: A Comparison Between China and Russia

\section{5}

2005-1: Keld Laursen \& Ammon Salter: My Precious - The Role of Appropriability Strategies in Shaping Innovative Performance

2005-2: Nicolai J. Foss \& Peter G. Klein: The Theory of the Firm and Its Critics: A Stocktaking and Assessment

2005-3: Lars Bo Jeppesen \& Lars Frederiksen: Why Firm-Established User Communities Work for Innovation: The Personal Attributes of Innovative Users in the Case of Computer-Controlled Music

2005-4: Dana B. Minbaeva: Negative Impact of HRM Complementarity on Knowledge Transfer in MNCs

2005-5: Kirsten Foss, Nicolai J. Foss, Peter G. Klein \& Sandra K. Klein: Austrian Capital 
Theory and the Link Between Entrepreneurship and the Theory of the Firm

2005-1: Nicolai J. Foss: The Knowledge Governance Approach

2005-2: Torben J. Andersen: Capital Structure, Environmental Dynamism, Innovation Strategy, and Strategic Risk Management

2005-3: Torben J. Andersen: A Strategic Risk Management Framework for Multinational Enterprise

2005-4: Peter Holdt Christensen: Facilitating Knowledge Sharing: A Conceptual Framework

2005-5 Kirsten Foss \& Nicolai J. Foss: Hands Off! How Organizational Design Can Make Delegation Credible

2005-6 Marjorie A. Lyles, Torben Pedersen \& Bent Petersen: Closing the Knowledge Gap in Foreign Markets - A Learning Perspective

2005-7 Christian Geisler Asmussen, Torben Pedersen \& Bent Petersen: How do we Capture "Global Specialization" when Measuring Firms' Degree of internationalization?

2005-8 Kirsten Foss \& Nicolai J. Foss: Simon on Problem-Solving: Implications for New Organizational Forms

2005-9 Birgitte Grøgaard, Carmine Gioia \& Gabriel R.G. Benito: An Empirical Investigation of the Role of Industry Factors in the Internationalization Patterns of Firms

2005-10 Torben J. Andersen: The Performance and Risk Management Implications of Multinationality: An Industry Perspective

2005-11 Nicolai J. Foss: The Scientific Progress in Strategic Management: The case of the Resource-based view

2005-12 Koen H. Heimeriks: Alliance Capability as a Mediator Between Experience and Alliance Performance: An Empirical Investigation Into the Alliance Capability Development Process

2005-13 Koen H. Heimeriks, Geert Duysters \& Wim Vanhaverbeke: Developing Alliance Capabilities: An Empirical Study

2005-14 JC Spender: Management, Rational or Creative? A Knowledge-Based Discussion

\section{6}

2006-1: Nicolai J. Foss \& Peter G. Klein: The Emergence of the Modern Theory of the Firm

2006-2: Teppo Felin \& Nicolai J. Foss: Individuals and Organizations: Thoughts on a Micro-Foundations Project for Strategic Management and Organizational Analysis

2006-3: Volker Mahnke, Torben Pedersen \& Markus Venzin: Does Knowledge Sharing 
Pay? An MNC Subsidiary Perspective on Knowledge Outflows

2006-4: Torben Pedersen: Determining Factors of Subsidiary Development

2006-5 Ibuki Ishikawa: The Source of Competitive Advantage and Entrepreneurial Judgment in the RBV: Insights from the Austrian School Perspective

2006-6 Nicolai J. Foss \& Ibuki Ishikawa: Towards a Dynamic Resource-Based View: Insights from Austrian Capital and Entrepreneurship Theory

2006-7 Kirsten Foss \& Nicolai J. Foss: Entrepreneurship, Transaction Costs, and Resource Attributes

2006-8 Kirsten Foss, Nicolai J. Foss \& Peter G. Klein: Original and Derived Judgement: An Entrepreneurial Theory of Economic Organization

2006-9 Mia Reinholt: No More Polarization, Please! Towards a More Nuanced Perspective on Motivation in Organizations

2006-10 Angelika Lindstrand, Sara Melen \& Emilia Rovira: Turning social capital into business? A study of Swedish biotech firms' international expansion

2006-11 Christian Geisler Asmussen, Torben Pedersen \& Charles Dhanaraj: Evolution of Subsidiary Competences: Extending the Diamond Network Model

2006-12 John Holt, William R. Purcell, Sidney J. Gray \& Torben Pedersen: Decision Factors Influencing MNEs Regional Headquarters Location Selection Strategies

2006-13 Peter Maskell, Torben Pedersen, Bent Petersen \& Jens Dick-Nielsen: Learning Paths to Offshore Outsourcing - From Cost Reduction to Knowledge Seeking

2006-14 Christian Geisler Asmussen: Local, Regional or Global? Quantifying MNC Geographic Scope

2006-15 Christian Bjørnskov \& Nicolai J. Foss: Economic Freedom and Entrepreneurial Activity: Some Cross-Country Evidence

2006-16 Nicolai J. Foss \& Giampaolo Garzarelli: Institutions as Knowledge Capital: Ludwig M. Lachmann's Interpretative Institutionalism

2006-17 Koen H. Heimriks \& Jeffrey J. Reuer: How to Build Alliance Capabilities

2006-18 Nicolai J. Foss, Peter G. Klein, Yasemin Y. Kor \& Joseph T. Mahoney: Entrepreneurship, Subjectivism, and the Resource - Based View: Towards a New Synthesis

2006-19 Steven Globerman \& Bo B. Nielsen: Equity Versus Non-Equity International Strategic Alliances: The Role of Host Country Governance

\section{7}

2007-1 Peter Abell, Teppo Felin \& Nicolai J. Foss: Building Micro-Foundations for the Routines, Capabilities, and Performance Links 
2007-2 Michael W. Hansen, Torben Pedersen \& Bent Petersen: MNC Strategies and Linkage Effects in Developing Countries

2007-3 Niron Hashai, Christian G. Asmussen, Gabriel R.G. Benito \& Bent Petersen: Predicting the Diversity of Foreign Entry Modes

2007-4 Peter D. Ørberg Jensen \& Torben Pedersen: Whether and What to Offshore?

2007-5 Ram Mudambi \& Torben Pedersen: Agency Theory and Resource Dependency Theory: Complementary Explanations for Subsidiary Power in Multinational Corporations

2007-6 Nicolai J. Foss: Strategic Belief Management

2007-7 Nicolai J. Foss: Theory of Science Perspectives on Strategic Management Research: Debates and a Novel View

2007-8 Dana B. Minbaeva: HRM Practices and Knowledge Transfer in MNCs

2007-9 Nicolai J. Foss: Knowledge Governance in a Dynamic Global Context: The Center for Strategic Management and Globalization at the Copenhagen Business School

2007-10 Paola Gritti \& Nicolai J. Foss: Customer Satisfaction and Competencies: An Econometric Study of an Italian Bank

2007-11 Nicolai J. Foss \& Peter G. Klein: Organizational Governance

2007-12 Torben Juul Andersen \& Bo Bernhard Nielsen: The Effective Ambidextrous Organization: A Model of Integrative Strategy Making Processes.

\section{8}

2008-1 Kirsten Foss \& Nicolai J. Foss: Managerial Authority When Knowledge is Distributed: A Knowledge Governance Perspective

2008-2 Nicolai J. Foss: Human Capital and Transaction Cost Economics.

2008-3 Nicolai J. Foss \& Peter G. Klein: Entrepreneurship and Heterogeneous Capital.

2008-4 Nicolai J. Foss \& Peter G. Klein: The Need for an Entrepreneurial Theory of the Firm.

2008-5 Nicolai J. Foss \& Peter G. Klein: Entrepreneurship: From Opportunity Discovery to Judgment.

2008-6 Mie Harder: How do Rewards and Management Styles Influence the Motivation to Share Knowledge?

2008-7 Bent Petersen, Lawrence S. Welch \& Gabriel R.G. Benito: Managing the Internalisation Process - A Theoretical Perspective.

2008-8 Torben Juul Andersen: Multinational Performance and Risk Management Effects: Capital Structure Contingencies. 
2008-9 Bo Bernard Nielsen: Strategic Fit and the Role of Contractual and Procedural Governance in Alliances: A Dynamic Perspective.

2008-10 Line Gry Knudsen \& Bo Bernhard Nielsen: Collaborative Capability in R\&D Alliances: Exploring the Link between Organizational and Individual level Factors.

2008-11 Torben Juul Andersen \& Mahesh P. Joshi: Strategic Orientations of Internationalizing Firms: A Comparative Analysis of Firms Operating in Technology Intensive and Common Goods Industries.

2008-12 Dana Minbaeva: HRM Practices Affecting Extrinsic and Intrinsic Motivation of Knowledge Receivers and their Effect on Intra-MNC Knowledge Transfer.

2008-13 Steen E. Navrbjerg \& Dana Minbaeva: HRM and IR in Multinational Corporations: Uneasy Bedfellows?

2008-14 Kirsten Foss \& Nicolai J. Foss: Hayekian Knowledge Problems in Organizational Theory.

2008-15 Torben Juul Andersen: Multinational Performance Relationships and Industry Context.

2008-16 Larissa Rabbiosi: The Impact of Subsidiary Autonomy on MNE Knowledge Transfer: Resolving the Debate.

2008-17 Line Gry Knudsen \& Bo Bernhard Nielsen: Organizational and Individual Level Antecedents of Procedural Governance in Knowledge Sharing Alliances.

2008-18 Kirsten Foss \& Nicolai J. Foss: Understanding Opportunity Discovery and Sustainable Advantage: The Role of Transaction Costs and Property Rights.

2008-19 Teppo Felin \& Nicolai J. Foss: Social Reality, The Boundaries of Self-fulfilling Prophecy, and Economics.

2008-20 Yves Dos, Nicolai J. Foss \& José Santos: A Knowledge System Approach to the Multinational Company: Conceptual Grounding and Implications for Research

2008-21 Sabina Nielsen \& Bo Bernhard Nielsen: Why do Firms Employ foreigners on Their Top Management Teams? A Multi-Level Exploration of Individual and Firm Level Antecedents

2008-22 Nicolai J. Foss: Review of Anders Christian Hansen's “Uden for hovedstrømmen - Alternative strømninger i økonomisk teori"

2008-23 Nicolai J. Foss: Knowledge, Economic Organization, and Property Rights

2008-24 Sjoerd Beugelsdijk, Torben Pedersen \& Bent Petersen: Is There a Trend Towards Global Value Chain Specialization? - An Examination of Cross Border Sales of US Foreign Affiliates 
2008-25 Vikas Kumar, Torben Pedersen \& Alessandro Zattoni: The performance of business group firms during institutional transition: A longtitudinal study of Indian firms

2008-26 Sabina Nielsen \& Bo B. Nielsen: The effects of TMT and Board Nationality Diversity and Compensation on Firm Performance

2008-27 Bo B. Nielsen \& Sabina Nielsen: International Diversification Strategy and Firm Performance: A Multi-Level Analysis of Firm and Home Country Effects

\section{9}

2009-1 Nicolai J. Foss: Alternative Research Strategies in the Knowledge Movement: From Macro Bias to Micro-Foundations and Multi-Level Explanation

2009-2 Nicolai J. Foss \& Peter G. Klein: Entrepreneurial Alertness and Opportunity Discovery: Origins, Attributes, Critique

2009-3 Nicolai J. Foss \& Dana B. Minbaeva: Governing Knowledge: The Strategic Human Resource Management Dimension

2009-4 Nils Stieglitz \& Nicolai J. Foss: Opportunities and New Business Models: Transaction Cost and Property Rights Perspectives on Entrepreneurships

2009-5 Torben Pedersen: Vestas Wind Systems A/S: Exploiting Global R\&D Synergies

2009-6 Rajshree Agarwal, Jay B. Barney, Nicolai J. Foss \& Peter G. Klein: Heterogeneous Resources and the Financial Crisis: Implications of Strategic Management Theory

2009-7 Jasper J. Hotho: A Measure of Comparative Institutional Distance

2009-8 Bo B. Nielsen \& Sabina Nielsen: The Impact of Top Management Team Nationality Diversity and International Experience on Foreign Entry Mode

2009-9 Teppo Felin \& Nicolai Juul Foss: Experience and Repetition as Antecedents of Organizational Routines and Capabilities: A Critique of Behaviorist and Empiricist Approaches

2009-10 Henk W. Volberda, Nicolai J. Foss \& Marjorie E. Lyles: Absorbing the Concept of Absorptive Capacity: How To Realize Its Potential in the Organization Field

2009-11 Jan Stentoft Arlbjørn, Brian Vejrum Wæhrens, John Johansen \& Torben Pedersen: Produktion i Danmark eller offshoring/outsourcing: Ledelsesmæssige udfordringer 


\section{0}

2010-1 Dana B. Minbaeva, Kristiina Mäkelä \& Larissa Rabbiosi: Explaining Intraorganizational Knowledge Transfer at the Individual Level

2010-2 Dana B.Minbaeva \& Torben Pedersen: Governing Individual Knowledge Sharing Behavior

2010-3 Nicolai J. Foss \& Peter G. Klein: Alertness, Judgment, and the Antecedents of Entrepreneurship

2010-4 Nicolai J.Foss \& Joseph T.Mahoney: Exploring Knowledge Governance

2010-5 Jasper J. Hotho, Florian Becker-Ritterspach \& Ayse Saka-Helmhout: Enriching Absorptive Capacity Through Social Interaction

2010-6 Nicolai J. Foss \& Bo B. Nielsen: Researching Collaborative Advantage: Some Conceptual and Multi-level Issues

2010-7 Nicolai J. Foss \& Nils Stieglitz: Modern Resource-Based Theory(ies)

2010-8 Christian Bjørnskov \& Nicolai J. Foss: Do Economic Freedom and Entrepreneurship Impact Total Factor Productivity?

2010-9 Gabriel R.G. Benito, Bent Petersen \& Lawrence S. Welch: Mode Combinations and International Operations: Theoretical Issues and an Empirical Investigation

\section{1}

2011-1 Peter D. Ørberg Jensen \& Bent Petersen: Human Asset Internalization and Global Sourcing of Services - A Strategic Management Analysis on Activity-level

2011-2 Mie Harder: Management Innovation Capabilities: A Typology and Propositions for Management Innovation Research

2011-3 Mie Harder: Internal Antecedents of Management Innovation: The effect of diagnostic capability and implementation capability 
2011-4 Mie Harder: Explaining Management Innovation Pervasiveness: The Role of Internal Antecedents

2011-5 Mie Harder: Internal Determinants of Product Innovation and Management Innovation: The Effect of Diagnostic Capability and Implementation Capability

2011-6 Nicolai J. Foss, Peter G. Klein \& Per L. Bylund: Entrepreneurship and the Economics of the Firm

2011-7 Nicolai J. Foss \& Jacob Lyngsie: The Emerging Strategic Entrepreneurship Field: Origins, Key Tenets and Research Gaps

2011-8 Nicolai J. Foss: Entrepreneurship in the Context of the Resource-based View of the Firm

2011-9 Bent Petersen, Gabriel R.G. Benito, Olesya Dovgan \& Lawrence Welch: Offshore outsourcing: A dynamic, operation mode perspective

2011-10 Bent Petersen, Gabriel R. G. Benito \& Lawrence Welch: Dynamics of Foreign Operation Modes and their Combinations: Insights for International Strategic Management

2011-11 Nicolai J. Foss: Teams, Team Motivation, and the Theory of the Firm

2011-12 Nicolai J. Foss: Knowledge Governance: Meaning, Nature, Origins, and Implications

2011-13 Nicolai J. Foss, Kirsten Foss \& Phillip C. Nell: MNC Organizational Form and Subsidiary Motivation Problems: Controlling Intervention Hazards in the Network MNC

2011-14 Kåre Moberg: Evaluating Content Dimensions in Entrepreneurship Education

\section{2}

2012-1 Nicolai J. Foss, Nicholas Argyres, Teppo Felin \& Todd Zenger: The Organizational Economics of Organizational Capability and Heterogeneity: A Research Agenda 
2012-2 Torben J. Andersen, Carina Antonia Hallin \& Sigbjørn Tveterås: A Prediction Contest: The Sensing of Frontline Employees Against Executive Expectations

2012-3 Peter G. Klein, Jay B. Barney \& Nicolai J. Foss: Strategic Entrepreneurship

2012-4 Kåre Moberg: The Impact of Entrepreneurship Education and Project-based Education on Students' Personal Development and Entrepreneurial Intentions at the Lower Levels of the Educational System: Too Much of Two Good Things? 